\title{
Chemosystematic aspects of polyisoprenylated benzophenones from the genus Clusia
}

\author{
MARIA CAROLINA ANHOLETI ${ }^{1,2}$, SELMA R. DE PAIVA ${ }^{2}$, \\ MARIA RAQUEL FIGUEIREDO ${ }^{3}$ and MARIA AUXILIADORA C. KAPLAN ${ }^{1}$ \\ ${ }^{1}$ Instituto de Pesquisas de Produtos Naturais, Universidade Federal \\ do Rio de Janeiro, Cidade Universitária, Centro de Ciências da Saúde, Bloco H, \\ Ilha do Fundão, 21941-902 Rio de Janeiro, RJ, Brasil \\ ${ }^{2}$ Laboratório de Botânica, Universidade Federal Fluminense, Instituto \\ de Biologia, Departamento de Biologia Geral, Campus do Valonguinho, \\ Outeiro de São João Batista, s/n, 24020-140 Niterói, RJ, Brasil \\ ${ }^{3}$ Laboratório de Química de Produtos Naturais, Far-Manguinhos, Fundação Oswaldo Cruz, \\ Avenida Brasil, 4365, Manguinhos, 21040-900 Rio de Janeiro, RJ, Brasil \\ Manuscript received on October 21, 2014; accepted for publication on December 18, 2014
}

\begin{abstract}
Benzophenone derivatives are special metabolites that arouse great scientific interest. The Clusiaceae family is known for producing large amounts of benzophenone derivatives with several isoprene residues on their structures, which are responsible for the observed complexity and structural variety in this class of substances, and also contribute to their biological activities. Clusia is an important genus belonging to Clusiaceae, with 55 different polyisoprenylated benzophenones identified so far. These substances were analyzed from biosynthetic and chemosystematic points of view, allowing the determination of characteristics regarding their production, accumulation and distribution within this genus. Polyisoprenylated benzophenones found in Clusia showed a high prenylation degree, with 2 to 5 isoprene units and a greater occurrence in flowers and fruits. Section Cordylandra showed a very similar occurrence of 2,4,6-trihydroxybenzophenone derivatives and bicyclo[3.3.1]nonane-2,4,9trione derivatives, the majority of them with 4 isoprene units. In section Anandrogyne there is a predominance of simple 2,4,6-trihydroxy-benzophenone derivatives, with 2 isoprene units, and in Chlamydoclusia predominates bicyclo[3.3.1] nonane-2,4,9-trione derivatives with 4 isoprene units. Although highly prenylated, these substances showed low oxidation indexes, which from an evolutionary perspective corroborates the fact that Clusiaceae is a family in transition, with some common aspects with both basal and derived botanical families.
\end{abstract}

Key words: Chemosystematics, Clusia, Clusiaceae, Polyisoprenylated benzophenones.

\section{INTRODUCTION}

Clusiaceae Lindl. (=Guttiferae Juss.) is a botanical family of wide geographical distribution, with widespread occurrence in the tropics. It is represented

Correspondence to: Maria Carolina Anholeti

E-mail: carolanholeti@gmail.com by 14 genera, and is currently inserted in the order Malpighiales. The genus Clusia comprises about 300400 species of neotropical distribution, being highly diversified in Central and South America (Stevens 2001). Many species belonging to this genus are used in folk medicine to treat health problems such 
as hypertension (García-González and Matamoros 1998), cardiovascular disorders (Caballero-George et al. 2001), headaches and syphilis (Barrios et al. 1991), infant oral candidiasis (Barbosa and Pinto 2003), rheumatism (Sanz-Biset et al. 2009), as painkillers and wound healers (Langenheim 2003).

The species of Clusia have channel systems that cross plant tissues producing resinous latex, which varies in abundance, density and color. These variations are observed not only among species but also among different organs of the same plant. It is believed that the produced latex plays a protective role, so that when the channels are injured its extravasation forms a defensive barrier against insects and/or microorganisms attack (Lokvam et al. 2000).

In addition to the latex, many species of Clusia produce resins in the stamina and/or pistils of the flowers. The floral resins are rare, limited to a few genera of tropical species and act as a reward to pollinators. Most of Clusia species are dioecious, with male and female flowers occurring on different individuals. This feature enhances the ecological importance of flower resins, since the bees collect this material to build nests and during this process perform pollination (Oliveira et al. 1996, Porto et al. 2000).

The chemical composition investigation of Clusia floral resins revealed that they consist mainly of polyisoprenylated benzophenones, a class of special metabolites that arouse great interest due to their structural complexity and broad spectrum of biological activities. These substances are also found in large quantities in fruits of Clusia (CuestaRubio et al. 2001, Delle Monache et al. 1991, Olivares et al. 1994, Oliveira et al. 1999, Piccinelli et al. 2005, Silva et al. 2012).

The purpose of this study is to characterize the genus Clusia as an important source of polyisoprenylated benzophenones and discuss their chemical and biological aspects, emphasizing their importance as chemical markers for the genus under a chemosystematics approach.

\section{MATERIALS AND METHODS}

Chemical data were collected from an extensive literature survey on Chemical Abstracts and specific literature databases. Polyisoprenylated benzophenones identified in Clusia species were listed and submitted to chemosystematics methodology (Santos et al. 2010). The system of classification of flowering plants used was that of APG III (2009).

HERBACEOUSNESS INDEX (HI)

First, the herbaceousness index (HI) for the genus Clusia was determined. It is a morphological evolutionary advance index based on the predominant habit of the species in the taxon under study. The value 100 is assigned to taxa formed only by herbaceous representatives, while the value 1 is assigned to taxa with exclusively arboreal representatives. For taxa where there is a ratio of arboreal and herbaceous representatives, intermediate values are assigned (Table I) (Borin and Gottlieb 1993).

TABLE I

Herbaceousness index (HI).

\begin{tabular}{cc}
\hline Habits & HI \\
\hline Trees & 1.0 \\
Trees predominating over shrubs & 12.5 \\
Trees and shrubs & 25.0 \\
Shrubs over trees & 37.5 \\
Shrubs & 50.0 \\
Shrubs predominating on herbs & 62.5 \\
Shrubs and herbs & 75.0 \\
Herbs predominating over shrubs & 87.5 \\
Herbs & 100.0 \\
\hline
\end{tabular}

NUMBER OF OCCURRENCES (NO)

The number of occurrences is a chemical parameter that provides the degree of relevance of a particular metabolic category for a chosen taxon. It is the sum of the number of different substances belonging to a specific chemical class for each species of a given taxon. The most relevant metabolic classes for each taxon, namely those with the highest values of NO, are then characterized as their chemical markers. Another important feature of this parameter is the fact 
that by counting " $n$ " times the same substance found in " $\mathrm{m}$ " different species, it is possible to characterize its production trend for a given taxon (Santos et al. 2010). The number of occurrences was the chemical parameter chosen to guide the distribution pattern of polyisoprenylated benzophenones within the genus Clusia and show their relevance as chemical markers.

OXIDATION INDEX (OI)

The oxidation index is a chemical parameter that shows the level of oxidation of a molecule. It is calculated by the formula: $\mathrm{OI}=(\mathrm{x}-\mathrm{h}) / \mathrm{n}$. Where " $\mathrm{x}$ " is the number of carbon-heteroatom bonds; " $\mathrm{h}$ " is the number of carbon-hydrogen bonds; and " $n$ " is the number of carbon atoms present in the molecule (Santos et al. 2010).

The values of evolutionary advance regarding the oxidation $\left(\mathrm{EA}_{\mathrm{o}}\right)$ of chemical substances within a given taxon are obtained by the ratio of the sum of the OIs of each substance by the number of occurrences of the chemical class to which it belongs (Santos et al. 2010).

\section{RESULTS}

\section{Chemosystematic Aspects of Polyisoprenylated}

BENZOPHENONES FROM Clusia

\section{Herbaceousness index (HI) for the genus Clusia}

For the genus Clusia the value 25.0 was assigned, due to the occurrence of trees and shrubs in similar proportion.

\section{Number of occurrences (NO)}

By the time this work was being written 55 different polyisoprenylated benzophenones had been identified in species belonging to the genus Clusia. The NO of this class of metabolites was 101 for this botanical genus.

\section{Distribution according to plant organs}

Polyisoprenylated benzophenones were identified in flowers, fruits, stems, branches and leaves of
Clusia species. There were no reports of studies involving roots. This class of metabolites was distributed in plant organs according to the number of different benzophenones identified in each organ (Fig. 1A). A higher number of benzophenones (35) was isolated from fruits of Clusia species, followed by flowers and stems (11).

When we take into account not only the number of substances found in each organ, but also the number of occurrences of each substance, there is a change in the distribution profile (Fig. 1B).

This difference may be better understood by taking the benzophenone clusianone (Fig. 2) as an example. This particular substance was found in stems, fruits and flowers of Clusia species, because of that, in Figure 1A, this substance counts as "1" in the bars corresponding to stems, flowers and fruits. However, this metabolite was identified in 10 different species of Clusia, being found in the flowers of 8 species $(\mathrm{NO}=8)$, in fruits of 1 species $(\mathrm{NO}=1)$ and in stems of 1 species $(\mathrm{NO}=1)$. Using this approach it is possible to notice that the occurrence of clusianone is more significant in the flowers than in the other mentioned organs, and in Figure 1B this substance counts as " 8 ", " 1 " and "1" in the bars corresponding, respectively, to flowers, fruits and stems of Clusia species.

In terms of the presence of benzophenones in other organs of Clusia species, no differences were observed in the approaches represented in Figures $1 \mathrm{~A}$ and $1 \mathrm{~B}$ regarding the distribution in stems, branches with leaves and leaves.

\section{Degree of prenylation}

The number of isoprene units found for benzophenones of the genus Clusia ranged from 2 to 5 . According to that, the substances were divided into four groups.

The parameter chosen to guide this distribution was again the number of occurrences, this time presented as a percentage of the number of occurrences $(\% \mathrm{NO})$, which was obtained by dividing the NO of each substance by the NO of this class 
of metabolites for the taxon, and then multiplied by 100 . The results show that tetraprenylated benzophenones are the most representative for the genus Clusia $(\% \mathrm{NO}=69 \%$ ) (Fig. 1C).

\section{Type of skeleton}

The benzophenones identified in the genus Clusia were arranged into six groups according to their structural similarity. The representativeness of each group to the taxon was expressed as the percentage of the number of occurrences of these substances within each group (Fig. 1D).

The results show that the most representative benzophenone groups for the genus Clusia are the bicyclo[3.3.1]nonane-2,4,9-trione derivatives and simple 2,4,6-trihydroxybenzophenone derivatives. The most representative substances in these groups are clusianone $(\mathrm{NO}=10)$ and weddellianone $\mathrm{A}$ $(\mathrm{NO}=8)$, respectively. 28,29-epoxiplukenetione A, sampsonione $\mathrm{G}$, plukenetione $\mathrm{C}$ and xerophenone
B are representatives of polyisoprenylated benzophenones derivatives with adamantyl skeleton, tricycle[4.3.1.13,8]undecane skeleton, tetracycle[7.3.1.17,11.0 $\left.0^{1,5}\right]$ tetradecane-10,12,13trione skeleton and 11-oxatricycle[4.3.1.1 $\left.{ }^{4,10}\right]$ undecane-7,9-dione skeleton, respectively (Fig. 2).

\section{Distribution by infrageneric sections}

One goal of chemosystematics is to assist in the rational pursuit of special metabolites. Therefore, in this paper, an attempt was made to locate within the genus Clusia the most promising groups with regard to the production of specific types of polyisoprenylated benzophenones.

The benzophenones identified in species of Clusia so far were distributed within the infrageneric sections proposed by Gustafsson et al. (2007), according to the type of skeleton and degree of prenylation, using the number of occurrences as the distribution parameter (Tables II and III).

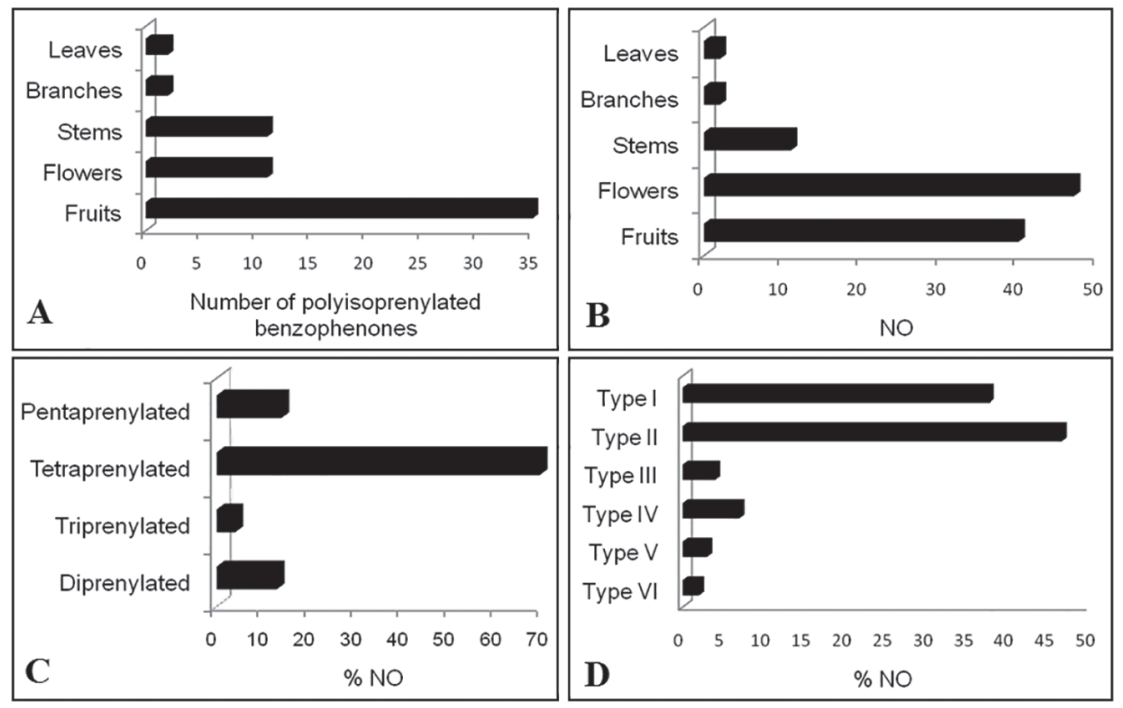

Figure 1 - Benzophenones in Clusia. (A) Number of different polyisoprenylated benzophenones identified in plant organs of Clusia species; (B) Number of occurrences (NO) for polyisoprenylated benzophenones in plant organs of Clusia species; (C) Percentage of the number of occurrences (\% NO) for polyisoprenylated benzophenones of the genus Clusia according to the degree of prenylation; (D) Percentage of the number of occurrences (\% NO) for polyisoprenylated benzophenones of the genus Clusia according to the type of skeleton. Type I = simple 2,4,6-trihydroxybenzophenone derivatives; Type II = bicyclo[3.3.1]nonane2,4,9-trione derivatives; Type III = derivatives with adamantyl skeleton; Type IV = derivatives with tricycle[4.3.1.1 $\left.1^{3,8}\right]$ undecane skeleton; Type $\mathrm{V}=$ derivatives with tetracycle[7.3.1.17,11.0 $\left.0^{1,5}\right]$ tetradecane-10,12,13-trione skeleton; Type VI = derivatives with 11-oxatricycle[4.3.1.1 $\left.1^{4,10}\right]$ undecane-7,9-dione skeleton. 
<smiles>C=C(C)C(CC=C(C)C)CC1(CC=C(C)C)C(O)=C(CC=C(C)C)C(=O)C(C(=O)c2ccccc2)=C1O</smiles>

Weddellianone A

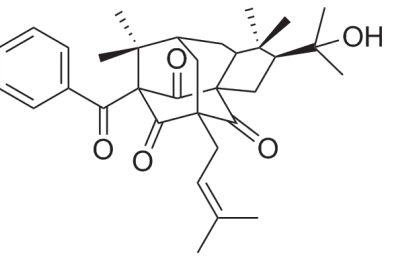

Sampsonione G

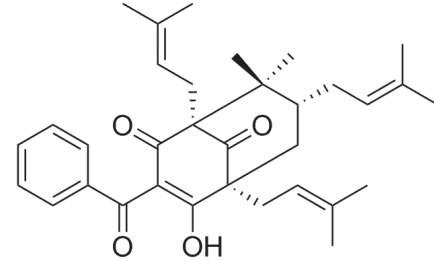

Clusianone

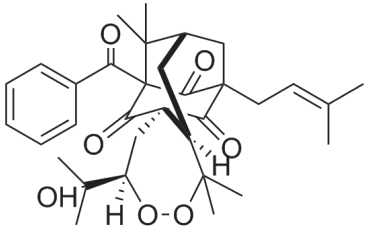

Plukenetione C

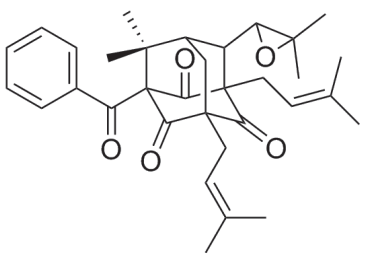

28,29-Epoxiplukenetione A<smiles>C=C(C)CC[C@H]1C[C@@]2(CC=C(C)C)C(=O)C(C(=O)c3ccccc3)=C(O)[C@@](CC=C(C)C)(C[C@H]1C)[C@@H]2O</smiles>

Xerofenone B

Figure 2 - Representatives of the different types of polyisoprenylated benzophenones skeletons identified in species of Clusia.

TABLE II

Number of occurrences for polyisoprenylated benzophenones within the infrageneric sections of the genus Clusia, according to the type of skeleton.

\begin{tabular}{|c|c|c|c|c|c|c|c|c|c|c|}
\hline \multirow[b]{2}{*}{ Type of skeleton } & \multicolumn{9}{|c|}{ Infrageneric Sections } & \multirow[b]{2}{*}{ Total } \\
\hline & Anandrogyne & Chlamydoclusia & Cordylandra & Criuva & $\begin{array}{l}\text { Flava } \\
\text { Group }\end{array}$ & $\begin{array}{c}\text { Omphalanthera } \\
\text { Complex }\end{array}$ & Phloianthera & Retinostemon & NP & \\
\hline $\begin{array}{l}\text { Simple } 2,4,6- \\
\text { trihydroxybenzophenone } \\
\text { derivatives }\end{array}$ & 6 & 3 & 14 & 0 & 0 & 1 & 5 & 0 & 9 & 38 \\
\hline $\begin{array}{l}\text { Bicyclo[3.3.1] } \\
\text { nonane-2,4,9-trione } \\
\text { derivatives }\end{array}$ & 1 & 15 & 15 & 1 & 2 & 1 & 1 & 3 & 8 & 47 \\
\hline $\begin{array}{l}\text { Derivatives with } \\
\text { adamantyl skeleton }\end{array}$ & 0 & 0 & 0 & 2 & 0 & 0 & 0 & 0 & 2 & 4 \\
\hline $\begin{array}{l}\text { Derivatives with } \\
\left.\text { tricycle[4.3.1.1 } 1^{3,8}\right] \\
\text { undecane skeleton }\end{array}$ & 0 & 0 & 0 & 5 & 0 & 0 & 0 & 0 & 2 & 7 \\
\hline $\begin{array}{l}\text { Derivatives with } \\
\text { tetracycle[7.3.1.17,11.0 } 1,5] \\
\text { tetradecane-10,12,13-trione } \\
\text { skeleton }\end{array}$ & 0 & 0 & 0 & 0 & 0 & 0 & 0 & 0 & 3 & 3 \\
\hline $\begin{array}{l}\text { Derivatives with } \\
\left.\text { 11-oxatricycle[4.3.1.1 } 1^{4,10}\right] \\
\text { undecane-7,9-dione } \\
\text { skeleton }\end{array}$ & 0 & 0 & 0 & 0 & 0 & 0 & 0 & 0 & 2 & 2 \\
\hline Total & 7 & 18 & 29 & 8 & 2 & 2 & 6 & 3 & 26 & 101 \\
\hline
\end{tabular}

$\mathrm{NP}=$ Species that have not yet been placed in infrageneric sections. 
TABLE III

Number of occurrences for polyisoprenylated benzophenones within the infrageneric sections of the genus Clusia, according to the degree of prenylation.

\begin{tabular}{|c|c|c|c|c|c|c|c|c|c|c|}
\hline \multirow{2}{*}{$\begin{array}{c}\text { Degree of } \\
\text { prenylation }\end{array}$} & \multicolumn{9}{|c|}{ Infrageneric Sections } & \multirow[b]{2}{*}{ Total } \\
\hline & Anandrogyne & Chlamydoclusia & Cordylandra & Criuva & $\begin{array}{l}\text { Flava } \\
\text { Group }\end{array}$ & $\begin{array}{c}\text { Omphalanthera } \\
\text { Complex }\end{array}$ & Phloianthera & Retinostemon & NP & \\
\hline Diprenylated & 5 & 0 & 0 & 0 & 0 & 0 & 0 & 0 & 8 & 13 \\
\hline Triprenylated & 0 & 1 & 0 & 1 & 0 & 1 & 0 & 0 & 1 & 4 \\
\hline Tetraprenylated & 2 & 13 & 20 & 6 & 2 & 1 & 6 & 3 & 17 & 70 \\
\hline Pentaprenylated & 0 & 4 & 9 & 1 & 0 & 0 & 0 & 0 & 0 & 14 \\
\hline Total & 7 & 18 & 29 & 8 & 2 & 2 & 6 & 3 & 26 & 101 \\
\hline
\end{tabular}

$\mathrm{NP}=$ Species that have not yet been placed in infrageneric sections.

Among the investigated sections, the highest occurrence of polyisoprenylated benzophenones was found in section Cordylandra ( $\mathrm{NO}=29)$. From the presented data it was also observed that the sections Anandrogyne, Chlamydoclusia and Cordylandra have distinct and well defined profiles relative to the production of benzophenones. In the first section there is a predominance of simple 2,4,6-trihydroxybenzophenone derivatives, in the second section predominates the bicyclo[3.3.1] nonane-2,4,9-trione derivatives, while in the last section, these two types of benzophenones have very close NOs.

Tetraprenylated benzophenones were present in all sections. Cordylandra showed the highest $\mathrm{NO}$ to this type of benzophenone ( $\mathrm{NO}=20$ ), while in Androgyne there was a predominance of diprenylated benzophenones $(\mathrm{NO}=5)$.

\section{Oxidation Index (OI) of polyisoprenylated benzophenones in Clusia}

The polyisoprenylated benzophenones from Clusia showed low values of OI. The value of evolutionary advance regarding the oxidation $\left(\mathrm{EA}_{\mathrm{o}}\right.$ ) for this class of metabolites was -0.49 .

\section{DISCUSSION}

All polyisoprenylated benzophenones share a common 13-carbon skeleton formed by 2 rings which are connected via a carbonyl group. The portion of the structure containing the A-ring is derived from the shikimate pathway, having benzoyl-CoA (or a derivative) as precursor. The other part of the structure, which contains the B-ring, has a polyketide origin and is produced by a reaction catalyzed by a benzophenone synthase (BPS) (Fig. 3) (Beerhues and Liu 2009).
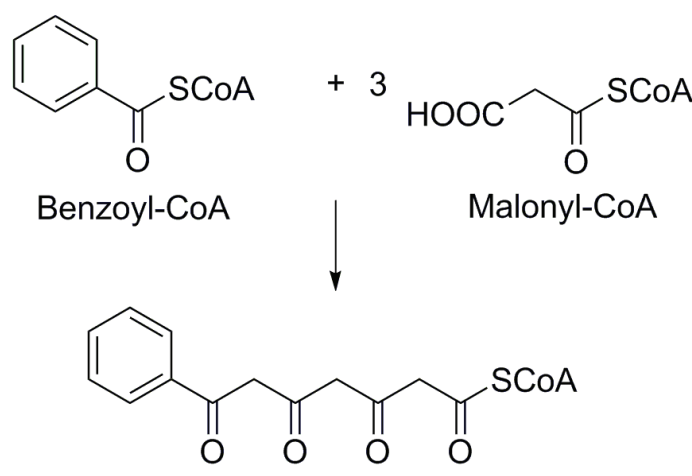

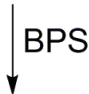

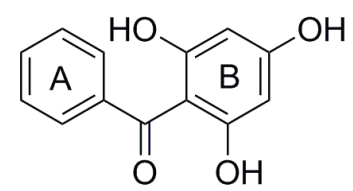

\section{2,4,6-Trihydroxybenzophenone}

Figure 3 - General pathway for the biosynthesis of benzophenones. Adapted from Beerhues and Liu (2009). 
The A-ring is found with 0,1 or 2 substituents, while the B-ring undergoes prenylation and cyclization to form groups of benzophenones with various types of structures (Bagget et al. 2005).

Most of the benzophenones isolated from Clusia species until this moment are devoid of substituents in A-ring, indicating that they are probably derived from benzoyl-CoA. Exceptions are the benzophenones guttiferone $\mathrm{E}$ and xanthochymol, which have a dihydroxylated A-ring, and hydroxynemorosone, with a monohydroxylated A-ring (Fig. 4A).

In the case of guttiferone $\mathrm{E}$ and xanthochymol the most likely precursor is protocatechuic acid, which goes through a similar mechanism to that of benzoyl-CoA, leading to the formation of maclurin (Fig. 4B), that after prenylation and cyclization reactions, is converted to the mentioned substances. Maclurin is also supposed to be an intermediate in the biosynthesis of 1,3,5,6-tetrahydroxyxanthones in species from the genus Garcinia (Clusiaceae) (Chantarasriwong et al. 2010). In fact, the conversion of benzophenones to xanthones represents an important biosynthetic branch point in different plants. Studies have shown that the mechanism behind this reaction probably involves an oxidative phenol coupling catalyzed by regioselective xanthone synthases, which are proposed to be cytochrome P450 oxidases (Peters et al. 1998).

In the case of hydroxynemorosone there is a hydroxyl group at position 3' of the A-ring. Previous studies show two possibilities for its origin: The first one was discussed by Beerhues (1996), who first identified the presence of a benzophenone synthase using cultured cells of Centaurium erythraea (Gentianaceae). The study showed the enzyme preference for the substrate 3-hydroxybenzoyl-CoA, that reacts with 3 units of malonyl-CoA leading to the formation of 2,3',4,6-tetrahydroxybenzophenone as intermediate. This in turn, can undergo prenylation and cyclization reactions to form hydroxynemorosone. The second possibility was described by Schmidt and Beerhues (1997), who showed that 2,3',4,6-tetrahydroxybenzophenone can also be synthesized from benzoyl-CoA. The researchers identified a benzophenone synthase in cell cultures of Hypericum androsaemum $\mathrm{L}$. (Hypericaceae) with higher affinity for this substrate rather than 3-hydroxybenzoyl-CoA. In this case 2,4,6-trihydroxybenzophenone is produced first, and then converted to 2,3',4,6-tetrahydroxybenzophenones by an enzyme designated as 3'-hydroxylase (Fig. 4C).

An important feature of the benzophenones found in species belonging to the family Clusiaceae is the presence of isoprene units. In the benzophenones of Clusia species the number of such terpene residues varies from two to five isoprene units, with tetraprenylated benzophenones being the most representative for the genus.

Prenylation of aromatic natural products plays an important role in the biosynthesis of chemically complex and structurally diverse molecules. In flavonoids, the substitution of the flavonoid ring system with prenyl units increases the lipophilicity and confers to the molecule a strong affinity to biological membranes. It is known that prenylation provides flavonoids with enhancement of antibacterial, anti-inflammatory, antioxidant, cytotoxic, larvicidal as well as estrogenic activities (Botta et al. 2005, Chen et al. 2014).

Dimethylallyl groups are the frequent substituents found in many natural products. In the case of polyisoprenylated benzophenones they are inserted through reactions of dimethylallyl pyrophosphate (DMAPP) units with the phloroglucinol ring (B-ring), mediated by prenyltransferases. Positions ortho or para to a phenol group, or positions adjacent to one or more carbonyl groups, are activated and make good candidates for $C$-alkylation (Dewick 2002). This explains why prenylation reactions occur only in ring B. 

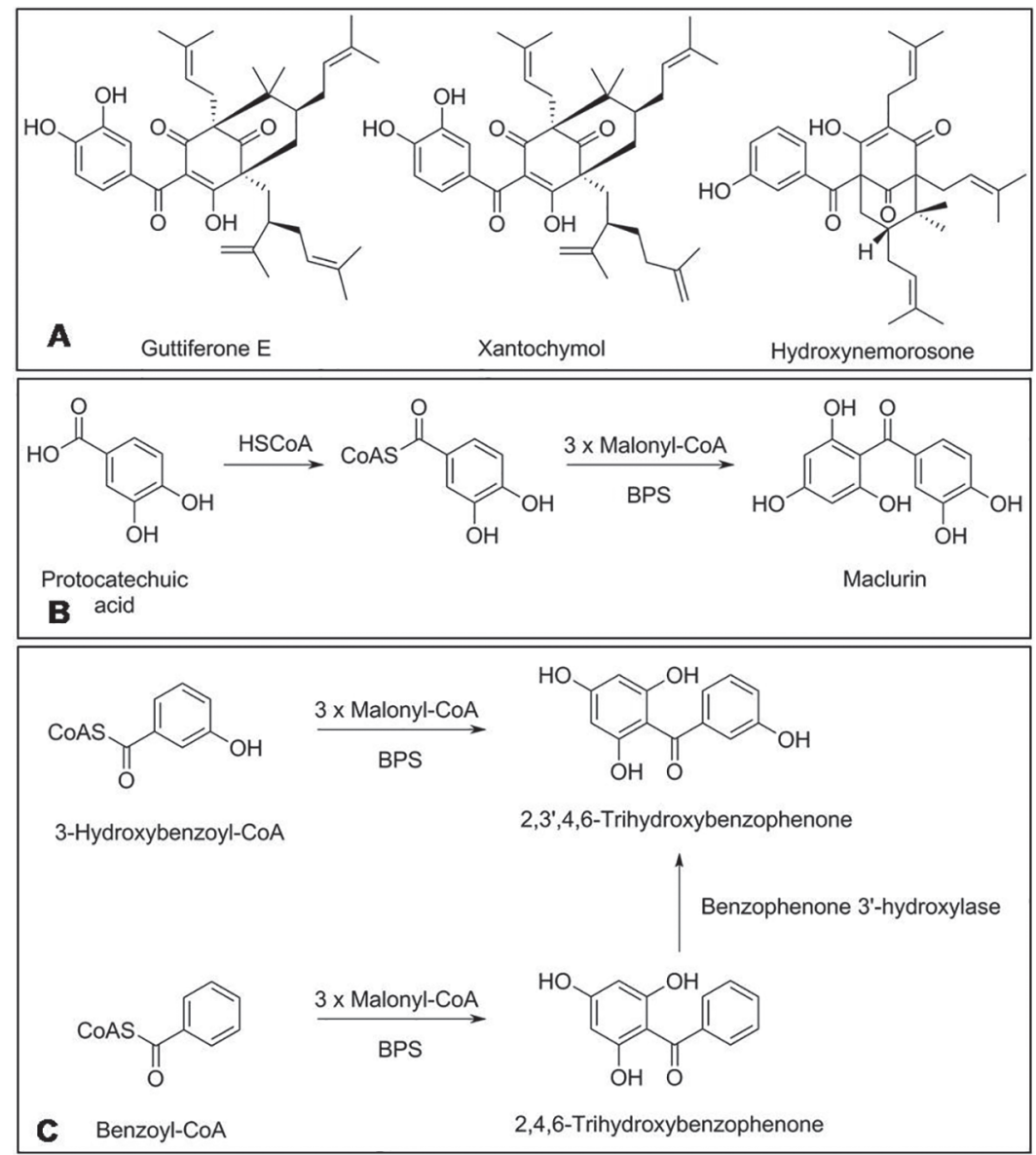

Figure 4 - Biosynthetic aspects of Clusia benzophenones. (A) Chemical structures of guttiferone E, xanthochymol and hydroxynemorosone; (B) Biosynthesis of maclurin (Adapted from Chantarasriwong et al. 2010); (C) Biosynthesis of 2,3',4,6-Trihydroxybenzophenone (Adapted from Schmidt and Beerhues 1997).

The presence of several isoprene units in the structures of the benzophenones found in family Clusiaceae arouse great interest about this class of special metabolites, not only due to the chemical complexity observed in many of these substances, but also due to the importance of these terpene residues for some of the biological activities presented by them.

Martins et al. (2009) demonstrated that the inhibitory activity on cysteine proteases and serine peptidases by polyisoprenylated benzophenones isolated from Garcinia brasiliensis (Clusiaceae) was directly related to the number of isoprene units present in the structure of these substances. The higher the degree of prenylation, the greater was the inhibitory activity displayed. Two synthetic benzophenones devoid of prenyl units were also tested and showed much lower activity than the polyisoprenylated benzophenones, acting only at very higher doses.

In addition to the dimethylallyl units, there are also benzophenones with isopentenyl and geranyl residues in Clusia. The terpene units are able to cyclize with hydroxyl groups in ortho position leading to the formation of up to five or six-membered heterocycles (Fig. 5A). Cyclizations 
can also occur as a result of carbon-carbon bonds, leading to complex skeletons (Boubakir et al. 2005, Kumar et al. 2013).

Benzophenones with a substituted bicyclo[3.3.1] nonane-2,4,9-trione core are the most representative group in Clusia species. Substances with this type of skeleton have been the subject of many studies of biological activity and have shown great potential, especially with regard to the search for new anticancer agents. A great example is nemorosone (Fig. 5B), the major component of Clusia rosea floral resins, which has shown cytotoxic activity in vitro against a broad panel of tumour cell lines (CuestaRubio et al. 2002, Díaz-Carballo et al. 2008a, b, Popolo et al. 2011).

Since the A-ring does not undergo prenylation reactions it can be inferred that the variety of skeletons found for polyisoprenylated benzophenones in the genus Clusia is related to the type, number and position of isoprene units in the B-ring, as well as the occurrence of cyclization arising from $\mathrm{C}-\mathrm{O}$ and/or C-C bond formation.
From a chemosystematic point of view, $C$-prenylation reactions are very rare in primitive woody Angiospermae, being common in advanced Angiospermae groups (Gottlieb 1990).

In literature, polyisoprenylated benzophenones are described as major components of floral resins from Clusia species. The results presented in this papershowed that these metabolites areactually more representative in the flowers than in other organs of Clusia species. Their importance for the genus is supported by several studies which demonstrate their ecological significance. According to Oliveira et al. (1996), Clusia floral resins act as a reward to pollinators, they polymerize slowly during bees nest construction, possibly providing a waterproof protection with antiviral and antimicrobial activity, characteristics attributed to benzophenones. Porto and co-workers (2000) identified the presence of polyisoprenylated benzophenones in Trigona bees nest extract, which showed antimicrobial activity against Bacillus subtilis, Candida albicans and Staphylococcus aureus.

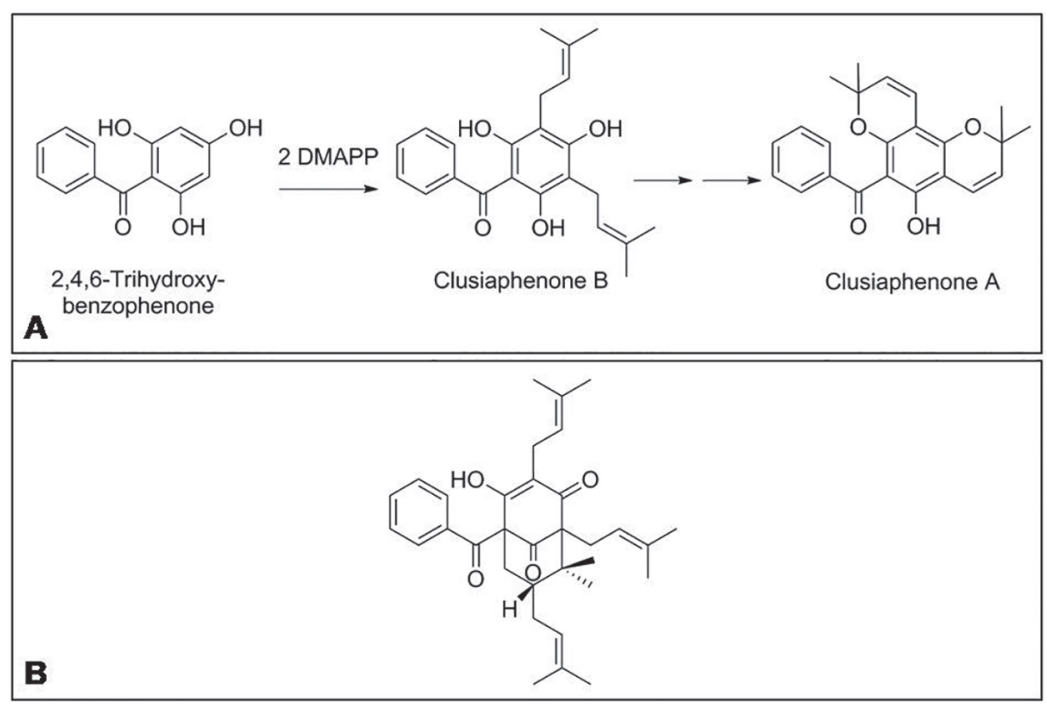

Figure 5 - Prenylation aspects of Clusia benzophenones. (A) Probable prenylation reaction of 2,4,6-trihydroxybenzophenone core leading to formation of clusiaphenone $\mathrm{B}$, which is then converted to clusiaphenone A by ciclization of the dimethylallyl groups; (B) Chemical structure of nemorosone. 
Over the years several attempts have been made to divide Clusia species into groups or infrageneric sections from information on data involving morphological, physiological and chemical characteristics, and also molecular biology data. Medina et al. (2006), showed the taxonomic significance of the epicuticular wax composition in species of the genus Clusia from Panama. They used the proportion of alkanes and triterpenes to divide the species into groups.

The occurrence of crassulacean acid metabolism (CAM) in the species belonging to this genus also enabled their division into groups based on the types of metabolism displayed by them. Some species are CAM constitutive, while others are able to change their metabolism from $\mathrm{C} 3$ (photosynthetic mechanism involving an intermediate formed by three carbons) to CAM under conditions of water restriction (Lüttge 2007, 2008).

The type of photosynthetic metabolism was one of the criteria used in the classifications proposed by Gehrig et al. (2003) and Gustafsson et al. (2007). The latter also took into account the production of resins by the species of the genus.

The present work showed that there are differences in the profile of benzophenone produced by species belonging to different infrageneric sections, both with regard to the type of skeleton and the degree of prenylation. This suggests that these substances could be used as chemical markers within the genus.

In addition to prenylation, oxidation reactions are also important from an evolutionary perspective. The reactions leading to most primary metabolites are based mainly on condensation (and reduction) and the pathways leading from these precursors to the special metabolites require oxidative steps. From this reasoning it is expected that most derived species have substances with higher oxidation indexes than that found in basal species (Gottlieb 1990).

It is interesting to notice that from an evolutionary point of view, the oxidation profile of the benzophenones found in Clusia does not corroborate the data concerning prenylation. As discussed above, a high degree of prenylation is expected in more derivative species, as well as a high degree of oxidation. For species belonging to the genus Clusia, we observed a high degree of prenylation, but a low level of oxidation in polyisoprenylated benzophenones.

The high prenylation profile is also not consistent with the herbaceousness index obtained for the genus Clusia. This parameter quantifies the evolutionary trend of abandonment of woody angiosperms character, in favour of herbacity, which occurred concomitant with retraction of the shikimate pathway and expansion of the acetate/ mevalonate pathway (evolutionary channeling) (Gottlieb and Borin 2012). In fact, the 13 carbons core of benzophenones has its origin partly in the shikimate pathway, as discussed previously, then the acetate/mevalonate pathway is activated, which gives a character of mixed biosynthesis for these substances.

It all starts to make sense when we observe the changes in the taxonomic position of the family Clusiaceae in recent years.

According to Dahlgren (1980) Clusiaceae was inserted in the order Theales, consisting of approximately 50 genera and 1200 species of wide geographical distribution, with high occurrence in the tropics. A classification proposed by the Angiosperm Phylogeny Group (APG) positioned first Clusiaceae in the order Ericales and then in Malpighiales, where it stands today. Some of the genera belonging to this family before, were regrouped giving rise to new families, such as Calophyllaceae and Hypericaceae. According to the most recent classification proposed by APG III, Theales no longer exists and becomes synonymous with Ericales, which is a more derived order than Malpighiales (Stevens 2001, APG III 2009).

The Malpighiales are one of the largest and most diverse orders of flowering plants. It comprises now 
36 families, 716 genera and 15.975 species and despite the wide morphological and molecular data existing, it still remains the least understood angiosperm order phylogenetically. The clade [Ochnaceae [[Clusiaceae + Bonnetiaceae] [Calophyllaceae [Hypericaceae + Podostemaceae]]]] has only weak support but its composition is consistent with morphology. The families from this clade also have a generally similar flavonoid spectrum (Stevens 2001).

\section{CONCLUSIONS}

This study showed that polyisoprenylated benzophenones are important special metabolites produced by Clusia species. These substances are known for presenting several biological activities and play a significant ecological role as major components of Clusia flower resins. They are produced in different organs of Clusia species, however, they occur mostly in flowers and fruits.

Clusia benzophenones were distributed within infrageneric sections based on their structural characteristics. The differences observed in the profile of benzophenones produced by species belonging to different infrageneric sections showed their importance as chemical markers of the genus.

From the biosynthetic point of view these substances are produced by mixed pathways. They present high degree of prenylation and low oxidation indexes, which in addition to the value of herbaceousness index attributed to the genus Clusia, show that Clusiaceae is a family in transition, with some common aspects to botanical families with both basal and derived characteristics and justifies the changes in the taxonomic position of the family Clusiaceae in recent years.

\section{ACKNOWLEDGMENTS}

The authors thank Coordenação de Aperfeiçoamento de Pessoal de Nível Superior (CAPES) and Conselho Nacional de Desenvolvimento Científico e Tecnológico (CNPq) for financial support and granted fellowships.

\section{RESUMO}

Derivados de benzofenonas despertam grande interesse científico. A família Clusiaceae é conhecida por produzir grandes quantidades dessas substâncias, com vários resíduos isoprênicos em suas estruturas, os quais são responsáveis pela complexidade e variedade estrutural observada nesta classe de substâncias, e também contribuem para suas atividades biológicas. Clusia é um gênero importante pertencente à família Clusiaceae, com 55 benzofenonas poliisopreniladas diferentes identificadas até o momento. Essas substâncias foram analisadas sob perspectivas biossintéticas e quimiossistemáticas, permitindo determinar características relacionadas à sua produção, acumulação e distribuição dentro desse gênero. As benzofenonas poliisopreniladas encontradas em Clusia apresentaram um grau elevado de prenilação, com 2 a 5 unidades isoprênicas e uma maior ocorrência em flores e frutos. A seção Cordylandra mostrou uma ocorrência muito semelhante de derivados de 2,4,6-triidroxibenzofenona e biciclo[3.3.1]nonano2,4,9-triona, a maioria deles com 4 unidades isoprênicas. $\mathrm{Na}$ seção Anandrogyne predominam derivados de 2,4,6-triidroxibenzofenona com 2 unidades isoprênicas, e em Chlamydoclusia predominam os derivados de biciclo[3.3.1]nonano-2,4,9-triona com 4 unidades isoprênicas. Embora altamente preniladas, essas substâncias mostraram índices de oxidação baixos, o que, sob uma perspectiva evolucionária, corrobora o fato de que Clusiaceae é uma família em transição, com alguns aspectos comuns tanto à famílias botânicas basais, quanto derivadas.

Palavras-chave: Quimiossistemática, Clusia, Clusiaceae, Benzofenonas poliisopreniladas.

\section{REFERENCES}

APG III. 2009. An update of the Angiosperm Phylogeny Group classification for the orders and families of flowering plants: APG III. Bot J Linn Soc 161: 105-121.

Bagget S, Mazzola EP And Kennelly EJ. 2005. The benzophenones: isolation, structural elucidation and biological activities. Studies Nat Prod Chem 32: 721-771.

BARBOSA WLR AND PINTO LN. 2003. Documentação e valorização da fitoterapia tradicional Kayapó nas aldeias A'Ukre e Pykanu - sudeste do Pará. Ver Bras Farmacogn 13: 47-49. 
Barrios M, Calvo M, Arguedas E and Castro O. 1991. Epicatequina en Clusia stenophylla y Clusia flava. Ing Cienc Quim 13: 27-28.

BEERHUES L. 1996. Benzophenone synthase from cultured cells of Centaurium erythraea. FEBS Lett 383: 264266.

BeERHUES L AND LIU B. 2009. Biosynthesis of biphenyls and benzophenones - evolution of benzoic acid-specific type III polyketide synthases in plants. Phytochemistry 70: 1719-1727.

BorIn MRMB AND GOTTLIEB OR. 1993. Steroids, taxonomic markers? Plant Syst Evol 184: 41-76.

Botta B, Vital A, Menendez P, Misiti D and Delle MONACHE G. 2005. Prenylated flavonoids: pharmacology and biotechnology. Curr Med Chem 12: 713-739.

Boubakir Z, Beuerle T, LIU B AND Beerhues L. 2005. The first prenylation step in hyperforin biosynthesis. Phytochemistry 66: 51-57.

CABAllero-George C, VANDERheyden PML, Solis PN, PIETERS L, Shahat AA, GuPTA MP, VAUQUELIN G AND VLIETINCK AJ. 2001. Biological screening of selected medicinal Panamanian plants by radioligand binding techniques. Phytomedicine 8: 59-70.

CHANTARASRIWONG O, BATOVA A, Chavasiri H AND THEODORAKIS EA. 2010. Chemistry and biology of the caged Garcinia xanthones. Chem Eur J 16: 9944-9962.

Chen X, Mukwaya E, Wong MS and Zhang Y. 2014. A systematic review on biological activities of prenylated flavonoids. Pharm Biol 52: 655-660.

Cuesta-Rubio O, Frontana-Uribe BA, Ramírez-Apan T AND CÁRDENAS J. 2002. Polyisoprenylated benzophenones in Cuban propolis: biological activity of nemorosone. $\mathrm{Z}$ Naturforsch C 57: 372-378.

Cuesta-Rubio O, Velez-CAstro H, Frontana-Uribe BA AND CÁRDENAS J. 2001. Nemorosone, the major constituent of floral resins of Clusia rosea. Phytochemistry 57: 279-283.

DAHLGREN RMT. 1980. A revised system of classification of the angiosperms. Bot J Linn Soc 80: 91-124.

Delle Monache F, Delle Monache G and Gacs-Baits E. 1991. Prenylated benzophenones from Clusia sandiensis. Phytochemistry 30: 2003-2005.

DEWICK PM. 2002. Medicinal natural products: a biosynthetic approach. $2^{\text {nd }}$ ed., J Wiley \& Sons Ltd., West Sussex.

DíAz-CARBAllo D, MALAK S, BARDENHEUER W, Freistuehler M AND Reusch HP. 2008a. Cytotoxic activity of nemorosone in neuroblastoma cells. J Cell Mol Med 12: 2598-2608.

DíAz-CARballo D, MALAK $\mathrm{S}$, Freistuehler $\mathrm{M}$, ElmaAGACli A, BARDENHEUER W AND REUSCH HP. 2008b. Nemorosone blocks proliferation and induces apoptosis in leukemia cells. Int J Clin Pharmacol Ther 46: 428-439.

García-GonzÁlez M AND Matamoros OM. 1998. Acción vaso-periférica del extracto acuoso de las hojas de Clusia coclensis (Clusiaceae). Rev Biol Trop 46: 575-578.
Gehrig HH, Aranda J, Cushman MA, Virgo A, Cushman JC, HAMMEL BE AND WinTER K. 2003. Cladogram of Panamanian Clusia based on nuclear DNA: implications for the origins of crassulacean acid metabolism. Plant Biol 5: 59-70.

GotTlieb OR. 1990. Phytochemicals: differentiation and function. Phytochemistry 29: 1715-1724.

GOTTLIEB OR AND BORIN MRMB. 2012. Químico-biologia quantitativa: um novo paradigma? Quim Nova 35: 2105 2114.

Gustafsson MHG, Winter K AND BITTRICH V. 2007. Diversity, phylogeny and classification of Clusia. In: LÜTTGE U (Ed), Clusia - A woody neotropical genus of remarkable plasticity and diversity, New York: Springer. New York, USA, p. 95-116.

Kumar S, Sharma S AND CHATTOPADHYAY SK. 2013. The potential health benefit of polyisoprenylated benzophenones from Garcinia and related genera: ethnobotanical and therapeutic importance. Fitoterapia 89: 86-125.

LANGENHEIM JH. 2003. Plant resins: chemistry, evolution, ecology, and ethnobotany. Portland: Timber Press, $586 \mathrm{p}$.

LOKVAM J, BRADDOCK JF, REICHARDT PB AND CLAUSEN TP. 2000. Two polyisoprenylated benzophenones from the trunk latex of Clusia grandiflora (Clusiaceae). Phytochemistry 55: 29-34.

LÜTTGE U. 2007. Clusia - woody neotropical genus of remarkable plasticity and diversity. Ecological Studies 54. New York: Springer, $275 \mathrm{p}$.

LÜTTGE U. 2008. Clusia: Holy Grail and enigma. J Exp Bot 59: $1503-1514$.

Martins FT, Assis DM, Santos MH, CAmpos I, Veloso MP, JULIANO MA, ALVES LC AND DORIGUETTO AC. 2009. Natural polyprenylated benzophenones inhibiting cysteine and serine proteases. Eur J Med Chem 44: 1230-1239.

Medina E, Aguiar G, Gómez M, Aranda J, Medina JD AND WINTER K. 2006. Taxonomic significance of the epicuticular wax composition in species of the genus Clusia from Panama. Biochem System Ecol 34: 319326.

Olivares EM, GonZalez JG AND Delle Monache F. 1994 Benzophenones from Clusia ellipticifolia. Phytochemistry 36: 473-475.

Oliveira CMA, PORTO ALM, BitTrich V AND MARSAIOLI AJ. 1999. Two polyisoprenylated benzophenones from the floral resins of three Clusia species. Phytochemistry 50: 1073-1079.

Oliveira CMA, PORTO AM, BitTrich V, VencATo I AND MARSAIOLI AJ. 1996. Floral resins of Clusia spp.: chemical composition and biological function. Tetrahedron Lett 37 : 6427-6430.

Peters S, Schmidt W AND Beerhues L. 1998. Regioselective oxidative phenol coupling of 2,3',4,6 -tetrahydroxybenzophenone in cell cultures of Centaurium erythraea Rafn. and Hypericum androsaemum L. Planta 204: 64-69. 
Piccinelli Al, Cuesta-Rubio O, Chica MB, Mahmood ND, Pagano B, PaVone M, Barone V and Rastrelli L. 2005. Structural revision of clusianone and 7-epiclusianone and anti-HIV activity of polyisoprenylated benzophenones. Tetrahedron 61: 8206-8211.

Popolo A, Piccinelli Al, Morello S, Sorrentino R, Cuesta-Rubio O, Rastrelli L and Pinto A. 2011. Cytotoxic activity of nemorosone in human MCF-7 breast cancer cells. Can J Physiol Pharmacol 89: 50-57.

Porto ALM, MACHADO SMF, DE Oliveira CMA, BitTrich V, AmARAL MDCE AND MARsaioli AJ. 2000. Polyisoprenylated benzophenones from Clusia floral resins. Phytochemistry 55: 755-768.

SANTOS MIS, LIMA HRP AND KAPLAN MAC. 2010. Metodologia em Quimiossistemática. In: KAPLAN MAC, ABREU HS, LIMA HRP and SOARES GLG (Eds), Abordagem quimiossistemática e evolução química de fanerógamas. Rio de Janeiro: Edur UFRRJ, Rio de Janeiro, Brasil, p. 39-50.
SANZ-BISET J, CAMPOS-DE-LA-CRUZ J, EPIQUIÉN-RIVERA MA AND CAÑIGUERAL S. 2009. A first survey on the medicinal plants of the Chazuta valley (peruvian Amazon). J Ethnopharmacol 122: 333-362.

SCHMIDT W AND BEERHUES L. 1997. Alternative pathways of xanthone biosynthesis in cell cultures of Hypericum androsaemum L. FEBS Lett 420: 143-146.

Silva MCA, Heringer AP, FigueIREdo MR AND PAIVA SR. 2012. Separation of clusianone from Clusia Fluminensis Planch. and Triana (Clusiaceae) by High Speed CounterCurrent Chromatography (HSCCC). J Liq Chrom Rel Technol 35: 2313-2321.

SteVens PF. 2001. Angiosperm Phylogeny Website. Version 12, July 2012 [and more or less continuously updated since]. Available at <http://www.mobot.org/MOBOT/ research/APweb/>. Access July 0914. 
